\title{
PEMBELAJARAN MEMBACA PERMULAAN MELALUI PERMAINAN BAHASA SISWA KELAS I SDN BULAKREJO MADIUN
}

\author{
Nur Samsiyah * \\ Apri Kartika Sari * \\ Yeni Sulistyaningrum **
}

\begin{abstract}
Early reading is a stage of learning reading for elementary school students of early grades. They learn to acquire the reading skill and techniques tosuccessfully decode passages. Learning atmosphere should be created through the language plays for reading. It goes with their characteristic of enjoying playing, Language playsplay a vital role to support their cognitive and social development. The current study aims to describe the process as well as the results of early reading through a language play at early grades of elementary school. Qualitatively approached, the current study involves participants of the first graders of the elementary school SDN BulakrejoMadiun. Data were collected through observation and documentation. Results show: (1) high achievement of average 80.7; (2) high enthusiasm specifically on the play batuloncatan (stepping stone); (3) the play could be carried out in and out of classroom and increasing their interest; and (4) headmaster, teachers and students appreciate the learning reading through the play.
\end{abstract}

Key words: Early Reading, Play

\begin{abstract}
Abstrak
Membaca permulaan merupakan tahapan proses belajar membaca bagi siswa sekolah dasar kelas awal. Siswa belajar untuk memeroleh kemampuan dan menguasai teknik-teknik membaca dan menangkap isi bacaan dengan baik. Suasana belajar harus dapat diciptakan melalui kegiatan permainan bahasa dalam pembelajaran membaca. Hal itu sesuai dengan karakteristik anak yang masih senang bermain. Permainan memiliki peran penting dalam perkembangan kognitif dan sosial anak. Penelitian ini bertujuan untuk mengetahui proses dan hasil membaca permulaan melalui permainan bahasa di kelas awal sekolah dasar. Penelitian ini menggunakan pendekatan kualitatif dengan subyek siswa Kelas I SDN Bulakrejo Madiun. Pengumpulan data yang digunakan ialah pengamatan dan dokumentasi. Hasil penelitian menunjukkan: (1) pembelajaran membaca melalui permainan bahasa memperoleh nilai rata-rata tinggi yaitu 80,7 ; (2) aktivitas siswa sangat antusias pada permainan batu loncatan; (3)
\end{abstract}

* Nur Samsiyah adalah Dosen Prodi PGSD FIP IKIP PGRI MADIUN

* Apri Kartika Sari adalah Dosen Prodi PGSD FIP IKIP PGRI MADIUN

** Yeni Sulistyaningrum adalah Mahasiswa Prodi PGSD FIP IKIP PGRI MADIUN 
kegiatan pembelajaran khususnya permainan batu loncatan digunakan siswa tidak hanya pada dilakukan di kelas tetapi dapat dipakai di luar kelas dan menarik minat siswa; dan (4) kepala sekolah, guru dan, siswa SDN Bulakrejo Madiun menanggapi positif terhadap pembelajaran membaca dengan menggunakan permainan bahasa.

Kata Kunci: Membaca Permulaan, Permainan

\section{A. PENDAhuluan}

Bahasa memiliki peranan penting bagi manusia. Menurut Santoso (2008:12) bahasa merupakan alat komunikasi yang penting yang digunakan dalam melakukan tindak komunikasi agar orang lain memahami pesan yang dimaksudkan. Standar kompetensi yang harus dicapai, melalui pembelajaran Bahasa Indonesia ialah meningkatkan kemampuan peserta didik untuk berkomununikasi dalam Bahasa Indonesia, baik secara lisan maupun tulisan serta menimbulkan penghargaan terhadap hasil cipta manusia. Pembelajaran Bahasa Indonesia di sekolah dasar (SD) secara khusus bertujuan mengembangkan kemampuan berbahasa Indonesia siswa sesuai dengan fungsi bahasa sebagai wahana berpikir dan wahana berkomunikasi untuk mengembangkan potensi intelektual, emosional, dan sosial. Bahasa sangat fungsional dalam kehidupan manusia, karena selain merupakan alat komunikasi yang paling efektif, berpikir pun menggunakan bahasa. Kemampuan berbahasa sangat penting, khususnya kemampuan baca-tulis atau literasi (melek huruf).

Azies dan Alwasilah (1996: 12) menyatakan bahwa di seluruh dunia masalah literasi atau melek huruf ini merupakan persoalan manusiawi terpenting dan mendasar persoalan pangan dan papan. Membaca adalah suatu proses yang dilakukan serta dipergunakan oleh pembaca untuk memperoleh pesan, yang hendak disampaikan oleh penulis melalui media kata-kata/bahasa tulis (Tarigan, 2008: 7). Sedangkan Slamet (2008: 66) mengemukakan membaca sebagai suatu proses yang menuntut agar kelompok kata yang merupakan suatu kesatuan akan terlihat dalam pandangan sekilas dan agar makna kata-kata secara individual akan dapat diketahui. Menurut pandangan whole language membaca tidak diajarkan sebagai suatu pokok bahasan yang berdiri sendiri, melainkan merupakan satu kesatuan dalam pembelajaran bahasa, bersama dengan ketrampilan berbahasa yang lain. Kenyataan tersebut dapat dilihat bahwa dalam proses pembelajaran bahasa, ketrampilan berbahasa tertentu dapat dikaitkan dengan ketrampilan berbahasa yang lain. Pengaitan ketrampilan berbahasa yang dimaksud tidak selalu melibatkan keempat ketrampilan berbahasa sekaligus, melainkan dapat hanya menyangkut dua ketrampilan saja sepanjang aktivitas berbahasa yang dilakukan bermakna.

Tujuan membaca permulaan di Kelas I adalah agar siswa dapat membaca kata-kata dan kalimat sederhana dengan lancar dan tepat (Depdikbud, 1994: 4). Kelancaran dan ketepatan anak membaca pada tahap belajar membaca permulaan dipengaruhi oleh keaktifan dan kreativitas guru yang mengajar di Kelas I. Guru memegang peranan yang strategis dalam meningkatkan ketrampilan membaca siswa. Peranan strategis tersebut menyangkut peran guru sebagai fasilitator, motivator, sumber belajar, dan organisator dalam proses pembelajaran. Guru yang 
berkompetensi tinggi akan sanggup melaksanakan tugas untuk mencerdaskan bangsa, mengembangkan pribadi manusia seutuhnya dan membentuk ilmuwan dan tenaga ahli. Menurut Badudu (1993: 131) guru dalam melaksanakan pembelajaran Bahasa Indonesia di SD s.d. SMU, terlalu banyak menyuapi tetapi kurang menyuruh siswa aktif membaca, menyimak, menulis, dan berbicara. Proses belajar-mengajar di kelas tidak relevan dengan yang diharapkan, akibatnya kemampuan membaca siswa rendah. Untuk mengoptimalkan pembelajaran membaca permulaan di SD salah satu alternatif yang dapat dilakukan ialah melalui permainan bahasa.

Selama ini masih banyak dijumpai sekolah-sekolah yang menerapkan sistem baca buku paket atau mengerjakan LKS saja, tanpa memedulikan siswa bisa membaca atau menulis. Hal tersebut terjadi karena guru menganggap bahwa siswa sudah membaca dari prasekolah atau sebelum siswa masuk kelas awal. Sebelum siswa masuk kelas awal, banyak siswa yang sudah menempuh belajar di PAUD, taman kanak-kanak, dan yang sederajat. Hal ini menyebabkan guru mengajarkan membaca tanpa memedulikan latar belakang siswa. Padahal siswa yang tidak bersekolah belum tentu telah diajarkan membaca oleh orangtuanya di rumah. Berdasarkan fenomena tersebut belum diketahui bagaimana pembelajaran permulaan melalui permainan bahasa. Permasalahan tersebut penting untuk diteliti karena jika diteliti hasilnya diharapkan akan memberikan kontribusi tentang rasionalitas pembelajaran membaca permulaan dan saran bagi lebih baiknya pembelajaran. Pembelajaran melalui permainan bahasa akan dilakukan di SDN Bulakrejo Madiun sebagai tempat penelitian.

Membaca adalah proses aktif dari pikiran yang dilakukan melalui mata terhadap bacaan. Pembaca dalam kegiatan membaca, memroses informasi dari teks yang dibaca untuk memperoleh makna. Membaca merupakan kegiatan yang penting dalam kehidupan sehari-hari, karena membaca tidak hanya untuk memperoleh informasi, tetapi berfungsi sebagai alat untuk memperluas pengetahuan bahasa seseorang. Dengan demikian, anak sejak kelas awal SD perlu memperoleh latihan membaca dengan baik khususnya membaca permulaan. Para ahli telah mendefiniskan tentang membaca dan tidak ada kriteria tertentu untuk menentukan suatu definisi yang dianggap paling benar. Menurut Baradja (1990: 23) membaca sebagai suatu kegiatan yang memberikan respons makna secara tepat terhadap lambang verbal yang tercetak atau tertulis. Pemahaman atau makna dalam membaca lahir dari interaksi antara persepsi terhadap simbol grafis dan ketrampilan bahasa serta pengetahuan pembaca. Dalam interaksi ini, pembaca berusaha menciptakan kembali makna sebagaimana makna yang ingin disampaikan oleh penulis dan tulisannya. Dalam proses membaca itu pembaca mencoba mengkreasikan apa yang dimaksud oleh penulis.

Dilain pihak, Gibbons (1993: 70-71) mendefinisikan membaca sebagai proses memperoleh makna dari cetakan. Kegiatan membaca bukan sekedar aktivitas yang bersifat pasif dan reseptif saja, melainkan menghendaki pembaca untuk aktif berpikir. Untuk memperoleh makna dari teks, pembaca harus menyertakan latar belakang bidang pengetahuannya, topik, dan pemahaman terhadap sistem bahasa itu sendiri. Tanpa hal-hal tersebut selembar teks tidak berarti apa-apa bagi pembaca. Sementara itu Tarigan (2008: 7) menyatakan bahwa membaca adalah suatu proses yang dilakukan serta dipergunakan oleh pembaca untuk memperoleh pesan, yang hendak disampaikan melalui media kata-kata atau 
bahasa tulis. Menurut Santoso (2008: 63) membaca merupakan kegiatan memahami bahasa tulis. Lebih lanjut Santoso mengungkapkan bahwa aktivitas membaca terdiri dari dua bagian, yaitu membaca sebagai proses dan membaca sebagai produk. Slamet (2008: 66) menyatakan bahwa hakikat membaca bukanlah sekedar menyuarakan lambang-lambang tertulis tanpa mempersoalkan apakah rangkaian kata/kalimat yang dilafalkan tersebut dipahami atau tidak, melainkan lebih daripada itu. Sedangkan Rahim (2007: 12) menyatakan bahwa proses membaca dimulai dengan sensori visual yang diperoleh melalui pengungkapan simbol-simbol grafis melalui indera penglihatan. Anak-anak belajar membedakan secara visual di antara simbol-simbol grafis (huruf atau kata) yang digunakan untuk mempresentasikan bahasa lisan.

Kegiatan membaca terjadi proses pengolahan informasi yang terdiri atas informasi visual dan informasi nonvisual (Smith, 1985: 12). Informasi visual, merupakan informasi yang dapat diperoleh melalui indera penglihatan, sedangkan informasi nonvisual merupakan informasi yang sudah ada dalam benak pembaca. Karena setiap pembaca memiliki pengalaman yang berbeda-beda dan dia menggunakan pengalaman itu untuk menafsirkan informasi visual dalam bacaan, maka isi bacaan itu akan berubah-ubah sesuai dengan pengalaman penafsirannya. Berdasarkan uraian di atas, membaca adalah proses interaksi antara pembaca dengan teks bacaan. Pembaca berusaha memahami isi bacaan berdasarkan latar belakang pengetahuan dan kompetensi kebahasaannya. Dalam proses pemahaman bacaan tersebut, pembaca pada umumnya membuat ramalan-ramalan berdasarkan sistem semantik, sintaksis, grafologis, dan kontekssituasi yang kemudian diperkuat atau ditolak sesuai dengan isi bacaan yangdiperoleh.

Sedangkan tujuan membaca seperti yang diungkapkan oleh Tarigan (2008: 9) adalah: (1) membaca untuk menemukan atau mengetahui penemuan-penemuan yang telah dilakukan oleh tokoh, apa-apa yang telah dibuat oleh tokoh, apa yang terjadi pada tokoh; (2) membaca untuk mengetahui mengapa hal itu merupakan topik yang baik dan menarik; (3) membaca untuk menemukan atau mengetahui apa yang terjadi pada setiap bagian cerita, apa yang terjadi mula-mula, kedua, dan selanjutnya; (4) membaca untuk menemukan serta mengetahui mengapa para tokoh merasakan seperti cara mereka itu, apa yang hendak diperlihatkan pengarang kepada para pembaca; (5) membaca untuk menemukan serta mengetahui apa-apa yang tidak biasa, tidak wajar mengenai seseorang tokoh, apa yang lucu dalam cerita atau apakah cerita itu benar atau tidak benar; (6) membaca untuk menemukan apakah tokoh berhasil atau tidak dengan ukuran-ukuran tertentu; dan (7) membaca untuk menemukan bagaimana caranya tokoh berubah, bagaimana hidupnya berbeda dari kehidupan yang dikenal.

Membaca permulaan dalam pengertian ini adalah membaca permulaan dalam teori ketrampilan, maksudnya menekankan pada proses penyandian membaca secara mekanikal. Membaca permulaan yang menjadi acuan adalah membaca merupakan proses recoding dan decoding. Membaca merupakan suatu proses yang bersifat fisik dan psikologis. Proses yang bersifat fisik berupa kegiatan mengamati tulisan secara visual. Dengan indera visual, pembaca mengenali dan membedakan gambar-gambar bunyi serta kombinasinya. Melalui proses recoding, pembaca mengasosiasikan gambar-gambar bunyi beserta kombinasinya itu dengan bunyi-bunyinya. Dengan proses tersebut, rangkaian 
tulisan yang dibacanya menjelma menjadi rangkaian bunyi bahasa dalam kombinasi kata, kelompok kata, dan kalimat yang bermakna.

Melalui proses decoding, gambar-gambar bunyi dan kombinasinya diidentifikasi, diuraikan kemudian diberi makna. Proses ini melibatkan knowledge of the world dalam skemata yang berupa kategorisasi sejumlah pengetahuan dan pengalaman yang tersimpan dalam gudang ingatan (Syafi'ie, 1999: 7). Proses membaca permulaan melibatkan tiga komponen, yaitu: (1) visual memory (VM); (2) phonological memory (PM); dan (3) semantic memory (SM). Lambanglambang fonem tersebut adalah kata, dan kata dibentuk menjadi kalimat. Proses pembentukan tersebut terjadi pada ketiganya. Pada tingkat VM: huruf, kata dan kalimat terlihat sebagai lambang grafis, sedangkan pada tingkat PM terjadi proses pembunyian lambang. Lambang tersebut juga dalam bentuk kata dan kalimat. Pada tingkatan membaca permulaan, pembaca belum memiliki ketrampilan kemampuan membaca yang sesungguhnya, tetapi masih dalam tahap belajar untuk memperoleh ketrampilan / kemampuan membaca. Membaca pada tingkatan ini merupakan kegiatan belajar mengenal bahasa tulis. Melalui tulisan itulah siswa dituntut dapat menyuarakan lambang-lambang bunyi bahasa tersebut, untuk memeroleh kemampuan membaca diperlukan tiga syarat, yaitu kemampuan membunyikan: (1) lambang-lambang tulis; (2) penguasaan kosakata untuk memberi arti; dan (3) memasukkan makna dalam kemahiran bahasa. Membaca permulaan merupakan suatu proses ketrampilan dan kognitif. Proses ketrampilan menunjuk pada pengenalan dan penguasaan lambang-lambang fonem, sedangkan proses kognitif menunjuk pada penggunaan lambang-lambang fonem yang sudah dikenal untuk memahami makna suatu kata atau kalimat.

Pembelajaran adalah proses, cara menjadikan orang atau makhluk hidup belajar. Sedangkan belajar adalah berusaha memperoleh kepandaian atau ilmu, berusaha tingkah laku atau tanggapan yang disebabkan oleh pengalaman (KBBI, 1996: 14). Sedangkan menurut Tarigan (2002: 23) pembelajaran adalah pengalaman belajar yang dialami oleh siswa dalam proses mencapai tujuan khusus pembelajaran. Lebih lanjut diungkapkan bahwa karakteristik pembelajaran Bahasa Indonesia, yaitu: (1) setiap pembelajaran berkaitan dengan kegiatan siswa; (2) setiap kegiatan pembelajaran berkaitan dengan kegiatan berbahasa; (3) setiap pembelajaran dimulai dengan kata kerja dan dapat dikembangkan secara kreatif; dan (4) setiap pembelajaran berkaitan dengan komponen PBM dan pendekatan CBSA, ketrampilan proses serta pendekatan komunikatif. Contoh rambu-rambu pembelajaran dapat dinyatakan sebagai berikut: (1) membicarakan hubungan atau kaitan dengan bahasa dan komunikasi; (2) memperbincangkan tentang keterpaduan aspek-aspek ketrampilan berbahasa atau kegiatan berbahasa dalam pelaksanaan suatu pembelajaran; dan (3) berkaitan dengan pengalokasian waktu pelaksanaan pembelajaran.

Hal senada dikemukakan oleh Akhadiah (1993: 68) yang berpendapat bahwa pembelajaran adalah proses pengelolaan lingkungan seseorang yang dengan sengaja dilakukan sehingga memungkinkan dia belajar untuk melakukan atau mempertunjukkan tingkah laku tertentu pula. Sedangkan belajar adalah suatu proses yang menyebabkan tingkah laku yang bukan disebabkan oleh proses pertumbuhan yang bersifat fisik, tetapi perubahan dalam kebiasaan, kecakapan, bertambah, berkembang daya pikir, sikap, dan lain-lain (Akhadiah, 1993:120). Undang-undang Nomor 20 Tahun 2003 tentang Sistem Pendidikan Nasional 
menyebutkan bahwa pembelajaran adalah proses interaksi peserta didik dengan pendidik dan sumber belajar pada suatu lingkungan belajar. Pembelajaran adalah proses yang disengaja yang menyebabkan siswa belajar pada suatu lingkungan belajar untuk melakukan kegiatan pada siatuasi tertentu.

Pembelajaran membaca permulaan diberikan di Kelas I dan Kelas II. Tujuannya adalah agar siswa memiliki kemampuan memahami dan menyuarakan tulisan dengan intonasi yang wajar, sebagai dasar untuk dapat membaca lanjut (Akhadiah, 1993: 31). Pembelajaran membaca permulaan merupakan tingkatan proses pembelajaran membaca untuk menguasai sistem tulisan sebagai representasi visual bahasa. Tingkatan ini sering disebut dengan tingkatan belajar membaca (learning to read). Membaca lanjut merupakan tingkatan proses penguasaan membaca untuk memeroleh isi pesan yang terkandung dalam tulisan. Tingkatan ini disebut sebagai membaca untuk belajar (reading to learn). Kedua tingkatan tersebut bersifat kontinum, artinya pada tingkatan membaca permulaan yang fokus kegiatannya penguasaan sistem tulisan, telah dimulai pula pembelajaran membaca lanjut dengan pemahaman walaupun terbatas. Demikian juga pada membaca lanjut menekankan pada pemahaman isi bacaan, masih perlu perbaikan dan penyempurnaan penguasaan teknik membaca permulaan (Syafi'ie,1999: 16).

Permainan merupakan alat bagi anak untuk menjelajahi dunianya, dari yang tidak dikenali sampai pada yang diketahui, dan dari yang tidak dapat diperbuatnya sampai mampu melakukannya (Semiawan, 2008: 20). Bermain bagi anak memiliki nilai dan ciri yang penting dalam kemajuan perkembangan kehidupan sehari-hari, yaitu:

1. Bermain memiliki arti. Pada permulaan setiap pengalaman bermain memiliki unsur risiko. Betapa pun sederhana permainannya, unsur risiko itu selalu ada;

2. Unsur lain adalah pengulangan. Dengan pengulangan anak memperoleh kesempatan mengkonsolidasikan ketrampilan yang harus diwujudkannya dalam berbagai permainandengan nuansa yang berbeda;

3. Fakta bahwa aktivitas permainan sederhana dapat menjadi kendaraan (vehice) untuk menjadi hajat permainan yang begitu kompleks, dapat dilihat dan terbukti mana kala mereka menjadi remaja;

4. Melalui bermain anak secara aman dapat menyatakan kebutuhannya tanpa dihukum atau terkena teguran.

Pada permulaan setiap pengalaman bermain memiliki risiko. Ada risiko bagi anak untuk belajar misalnya naik sepeda sendiri dan belajar meloncat. Unsur lain adalah pengulangan. Anak mengkonsolidasikan ketrampilannya yang harus diwujudkannya dalam berbagai permainan dengan nuansa yang berbeda. Dengan cara ini anak memperoleh pengalaman tambahan untuk melakukan aktivitas lain. Melalui permainan anak dapat menyatakan kebutuhannya tanpa dihukum atau terkena teguran misalnya bermain boneka diumpamakan sebagai adik yang sesungguhnya (Semiawan, 2002: 21). Menurut Tarigan (2002: 33) kegiatan bermain sangat penting dalam pengembangan kemampuan berbahasa anak. Seringkali mereka berperilaku sebagai anak atau orang yang lebih tua, bahkan ada yang berperan sebagai guru atau murid dalam permainan sekolah-sekolahan. Dalam permainan itu mereka seolah-olah berdrama dan tanpa disadari mereka berlatih berbicara dan menyimak. 
Berkaitan dengan permainan Pellegrini dan Saracho berpendapat permainan memiliki sifat, yakni: (1) permaianan dimotivasi secara personal, karena memberi rasa kepuasan; (2) pemain lebih asyik dengan aktivitas permainan (sifatnya spontan) ketimbang pada tujuannya; (3) aktivitas permainan dapat bersifat nonliteral; (4) permainan bersifat bebas dari aturan-aturan yang dipaksakan dari luar, dan aturan-aturan yang ada dapat dimotivasi oleh para pemainnya; dan (5) permainan memerlukan keterlibatan aktif dari pihak pemainnya (Wood, 1996: 3). Menurut Framberg permainan merupakan aktivitas yang bersifat simbolik, yang menghadirkan kembali realitas dalam bentuk pengandaian misalnya, bagaimana jika, atau apakah jika yang penuh makna (Root, 1995: 45). Dalam hal ini permainan dapat menghubungkan pengalamanpengalaman menyenangkan atau mengasyikkan, bahkan ketika siswa terlibat dalam permainan secara serius dan menegangkan sifat sukarela dan motivasi datang dari dalam diri siswa sendiri secara spontan. Menurut Hidayat (1980: 5) permainan memiliki ciri-ciri sebagai berikut: (1) adanya seperangkat peraturan yang eksplisit yang mesti diindahkan oleh para pemain; dan (2) adanya tujuan yang harus dicapai pemain atau tugas yang mesti dilaksanakan.

Permainan bahasa merupakan perminan untuk memperoleh kesenangan dan untuk melatih ketrampilan berbahasa (menyimak, berbicara, membaca, dan menulis). Apabila suatu permainan menimbulkan kesenangan tetapi tidak memperoleh ketrampilan berbahasa tertentu, maka permainan tersebut bukan permainan bahasa. Sebaliknya, apabila suatu kegiatan melatih ketrampilan bahasa tertentu, tetapi tidak ada unsur kesenangan maka bukan disebut permainan bahasa. Dapat disebut permainan bahasa, apabila suatu aktivitas tersebut mengandung kedua unsur kesenangan dan melatih ketrampilan berbahasa (menyimak, berbicara, membaca, dan menulis). Setiap permainan bahasa yang dilaksanakan dalam kegiatan pembelajaran harus secara langsung dapat menunjang tercapainya tujuan pembelajaran. Anak-anak pada usia 6 s.d. 8 tahun masih memerlukan dunia permainan untuk membantu menumbuhkan pemahaman terhadap diri mereka. Pada usia tersebut, anak-anak mudah merasa jenuh belajar di kelas apabila dijauhkan dari dunianya yaitu dunia bermain. Permainan hampir tak terpisahkan dengan kehidupan manusia. Baik bayi, anak-anak, remaja, dan orang dewasa semua membutuhkan permainan. Tentunya dengan jenis dan sifat permainan yang berbeda-beda sesuai dengan jenis kelamin, bakat, dan minat masing-masing.

Tujuan utama permainan bahasa bukan semata-mata untuk memperoleh kesenangan, tetapi untuk belajar ketrampilan berbahasa tertentu misalnya menyimak, berbicara, membaca, dan menulis. Aktivitas permainan digunakan sebagai alat untuk mencapai tujuan pembelajaran dengan cara yang menyenangkan. Menurut Dewey interaksi antara permainan dan pembelajaran akan memberikan pengalaman belajar yang sangat penting bagi anak-anak (Polito, 1994). Menang dan kalah bukan merupakan tujuan utama permainan. Dalam setiap permainan terdapat unsur rintangan atau tantangan yang harus dihadapi. Tantangan tersebut kadang-kadang berupa masalah yang harus diselesaikan atau diatasi, kadang pula berupa kompetisi. Masalah yang harus diselesaikan itulah yang dapat melatih ketrampilan berbahasa. Alat permainan baik realistik maupun imajinatif, buatan pabrik maupun alamiah memiliki peranan yang cukup besar dalam membantu merangsang anak dalam menggunakan bahasa. Keberadaan alatalat permainan dapat membantu dan meningkatkan daya imajinasi anak. 
Salah satu permainan yang digunakan adalah permainan kata dan huruf yang dapat memberikan suatu situasi belajar yang santai dan menyenangkan. Siswa dengan aktif dilibatkan dan dituntut untuk memberikan tanggapan dan keputusan. Dalam memainkan suatu permainan, siswa dapat melihat sejumlah kata berkali-kali, namun tidak dengan cara yang membosankan. Guru perlu banyak memberikan sanjungan dan semangat. Hindari kesan bahwa siswa melakukan kegagalan. Jika permainan sukar dilakukan oleh siswa, maka guru perlu membantu agar siswa merasa senang dan berhasil dalam belajar. Permainan bahasa yang dapat dilakukan adalah memilih kata, melengkapi kalimat, dan batu loncatan. Permainan batu loncatan tidak hanya menggunakan kata tetapi dapat juga diubah menjadi sebuah permainan pembentukan kalimat. Dengan memasukkan kata kerja dan bagian-bagian lain dari bahasa lisan. Siswa harus melompat ke bundaran-bundaran itu dalam urutan yang benar agar tersusun sebuah kalimat.

Guru dalam pembelajaran Bahasa Indonesia, dapat melakukan simulasi pembelajaran dengan menggunakan kartu berseri (flash card). Kartu-kartu berseri tersebut dapat berupa kartu bergambar, kartu huruf, kartu kata, dan kartu kalimat. Dalam pembelajaran membaca permulaan guru dapat menggunakan strategi bermain dengan memanfaatkan kartu-kartu huruf. Kartu-kartu huruf tersebut digunakan sebagai media dalam permainan menemukan kata. Siswa diajak bermain dengan menyusun huruf-huruf menjadi sebuah kata yang berdasarkan teka-teki atau soal-soal yang dibuat oleh guru. Titik berat latihan menyusun huruf ini adalah ketrampilan mengeja suatu kata.

Berdasarkan hasil observasi awal di SDN Bulakrejo Madiun, peneliti mendapatkan gambaran tentang siswa yang kurang aktif dalam menerima pelajaran. Siswa terlihat bosan dengan penjelasan guru, ini terlihat siswa yang lebih banyak bermain sendiri dengan teman-temannya. Kondisi kelas yang ditempati siswa memang sangat bersih, namun kebersihan itu justru bersih dari segala alat peraga dan hasil karya siswa. Berdasarkan hasil observasi tersebut peneliti memperoleh gambaran permasalahan siswa kurang aktif dalam belajar dan malas membaca. Selain itu siswa tidak memiliki buku-buku cerita untuk digunakan sekedar membaca. Penelitian ini dilakukan untuk memberikan kontribusi dalam menyelesaikan masalah yang berkaitan proses pembelajaran membaca permulaan melalui permainan bahasa dan hasil pembelajaran di kelas awal siswa SDN Bulakrejo Kecamatan Madiun. Penelitian ini bertujuan untuk mengetahui proses dan hasil pembelajaran membaca permulaan melalui permainan bahasa di kelas awal siswa SDN Bulakrejo Kecamatan Madiun. Penelitian ini diharapkan dapat meningkatkan pemahaman dan kelancaran membaca permulaan dengan permainan bahasa bagi siswa dan memberikan tambahan pengayaan cara mengajar dengan bantuan permainan.

\section{B. METODE PENELITIAN}

Penelitian ini menggunakan pendekatan kualitatif. Jenis desain penelitian yang digunakan adalah penelitian deskriptif yakni studi untuk menemukan fakta dan interpretasi yang tepat mengenai pembelajaran membaca permulaan melalui permainan bahasa sehingga dapat digunakan untuk studi penelitian selanjutnya. Sedangkan bentuk operasional data penelitian ini ialah melalui pendekatan kualitatif deskriptif yaitu berupa narasi, cerita, pengaturan informan, dokumen- 
dokumen pribadi seperti foto, catatan pribadi, perilaku, gerak tubuh, dan banyak hal yang tidak didominasi angka-angka sebagaimana penelitian kuantitatif. Penelitian ini dilakukan di SDN Bulakrejo Balerejo Madiun. Sumber data yang digunakan yaitu siswa Kelas I SDN Bulakrejo Balerejo Madiun yang berjumlah 22 siswa yang terdiri dari 12 laki-laki dan 10 perempuan.

Pengumpulan data adalah prosedur yang sistematis dan standar untuk memperoleh data yang diperlukan. Dalam rangka kepentingan pengumpulan data, teknik yang digunakan observasi, tes, dan studi dokumentasi. Langkah analisis data melalui beberapa tahap yaitu: pengumpulan data, mengelompokkannya, memilih dan memilah data, lalu kemudian menganalisanya. Analisis data ini berupa narasi dari rangkaian hasil penelitian yang muaranya untuk menjawab rumusan masalah. Analisis data penelitian ini dilakukan dengan analisis data kualitatif. Anggoro (2009: 18) menyatakan bahwa penelitian kualitatif merupakan bagian integral dari pengumpulan data di lapangan. Kegiatan analisis dilakukan secara simultan sepanjang periode penelitian.

\section{HASIL DAN PEMBAHASAN}

Jenis pembelajaran membaca yang dilaksanakan adalah membaca permulaan. Berdasarkan hasil pengamatan siswa terhadap objek-objek konkret di sekitar sekolahnya. Tema pembelajaran yang dipilih adalah lingkungan sekitar. Sejalan dengan tahapan membaca permulaan dengan penerapan permainan bahasa tersebut, guru menyusun dua rencana pembelajaran. Masing-masing rencana pembelajaran disajikan dalam waktu 2 x 35 menit, sehingga secara keseluruhan dilakukan dalam dua kali pertemuan. Rencana pembelajaran membaca permulaan pada tahap pertama dilaksanakan pada pertemuan pertama dengan alokasi waktu 2 x 35 menit. Tujuan pembelajaran pada tahap ini adalah siswa dapat: (1) mengucapkan kata dan kalimat dengan benar; (2) melalui kegiatan pemilihan kartu kata siswa dapat mencocokkan kartu kata dengan gambar yang benar; (3) melengkapi kalimat dengan tepat; dan (4) membaca penggalan kalimat dan kalimat sederhana dengan benar. Rencana pembelajaran dilakukan melalui tiga kegiatan belajar mengajar, yakni: (1) kegiatan awal; (2) kegiatan inti; dan (3) kegiatan akhir.

Media pembelajaran yang digunakan adalah kartu huruf, kartu kata, dan kalimat yang dirancang peneliti bersama anggota. Gambar tersebut dipakai sebagai model atau contoh mencocokkan gambar dengan kata. Metode pembelajaran yang diterapkan adalah ceramah, tanya jawab, pengamatan, dan penugasan. Penilaian pembelajaran yang direncanakan meliputi penilaian proses dan produk. Guru melaksanakan penilaian proses dengan lembar pengamatan yang mengacu pada aktivitas dan kreativitas siswa dalam pembelajaran. Sedang penilaian produk mengacu pada hasil akhir membaca siswa. Aspek yang dinilai mencakup: (1) kelancaran; (2) kejelasan suara; (3) ketepatan ejaan dan intonasi; dan (4) kesesuaian kalimat dengan bacaan. Metode pembelajaran yang diterapkan adalah ceramah, tanya jawab, dan permainan. Pada penerapan permainan bahasa dalam pembelajaran membaca permulaan, peneliti bertindak sebagai fasilitator, motivator, dan kolaborator yang memberikan arahan dan bimbingan dalam melakukan kegiatan pembelajaran.

Guru melaksanakan penilaian dengan lembar pengamatan terhadap aktivitas, kreativitas, dan kerja sama siswa dalam: (1) mengikuti penjelasan dan 
arahan guru; (2) tanya jawab baik dengan antarteman maupun guru; (3) kegiatan membaca siswa; dan (4) mengikuti permainan batu loncatan. Peneliti melaksanakan pengamatan selama proses pembelajaran berlangsung. Data yang dikumpulkan guru diperoleh dari hasil pengamatannya terhadap kegiatan nyata yang dilakukan siswa dan dianalisis untuk mengukur kompetensi dan unjuk kerjanya (performansinya) selama mengikuti pembelajaran. Data yang diperoleh guru dari hasil penerapan permainan bahasa dalam siswa Kelas I SDN Bulakrejo Madiun seperti pada Tabel 1.

Tabel 1 Hasil Nilai Membaca Siswa

\begin{tabular}{clc}
\hline No & \multicolumn{1}{c}{ Nama siswa } & Nilai \\
\hline 1 & Dimas Dwi S. & 67 \\
2 & Adi Jaya K. & 91 \\
3. & Anisa Nur Afifa & 83 \\
4. & Arofatulloh Yoga A. & 91 \\
5. & Cinderila Mega M. & 83 \\
6 & Doni Setia Buil Mdi & 91 \\
7 & Elga Puspita Dewi & 91 \\
8 & Eva Arista Meylani & 75 \\
9 & Faridha Mashuriyah & 83 \\
10 & Muhammad Aril M. & 83 \\
11 & Muhammad Nisar A. & 67 \\
12 & Noval Dwi W. S. & 58 \\
13 & Ridwan Miqdam & 91 \\
14 & Risqianafi Cahya P. & 67 \\
15 & Rizal Fauzi & 91 \\
16 & Riyan Deo Saputra & 75 \\
17 & Silvia Kartikasari & 58 \\
18 & Thorig Shohiful W. & 75 \\
19 & Tirtakumala Kejora & 91 \\
20 & Udey Nur Rochman & 91 \\
21 & Verdea Citra W. R & 91 \\
22 & Natasya Elvaryani & 83 \\
\hline
\end{tabular}

Berdasarkan Tabel 1, hasil membaca siswa melalui permainan kartu kata dan kalimat diperoleh rata-rata 80,7. Hasil nilai yang diperoleh siswa masih ada yang dibawah rata-rata sebanyak 6 siswa. Hal ini dikarenakan siswa membaca kurang lancar sehingga nilainya kurang. Berdasarkan hasil tanya jawab banyak siswa yang tidak mempunyai bacaan baik di rumah maupun di sekolah. Berdasarkan hasil membaca siswa pada pertemuan pertama pada kegiatan pembelajaran siswa Kelas I SDN Bulakrejo Madiun memperoleh nilai rata-rata yang tinggi. Kegiatan pembelajaran terdiri dari membaca kata dan kalimat, melengkapi kalimat rumpang, dan permainan batu loncatan. Pembelajaran disesuaikan dengan tujuan pembelajaran yang ingin dicapai pada rencana pembelajaran yang telah disusun. Hal ini sesuai dengan pendapat Tarigan (2002: 23) yang menyatakan bahwa pembelajaran adalah pengalaman belajar yang dialami oleh siswa dalam proses mencapai tujuan khusus pembelajaran.

Membaca permulaan diberikan di kelas awal terutama Kelas I sekolah dasar. Hal ini berguna sebagai dasar dalam membaca lanjut. Selain itu membaca tidak hanya diperlukan dalam mata pelajaran bahasa Indonesia saja, tetapi mata 
pelajaran lain juga membutuhkan ketrampilan membaca yang baik. Hal ini dipertegas dengan pernyataan Akhadiah (1993: 31) yang menyatakan bahwa tujuan membaca adalah agar siswa memiliki kemampuan memahami dan menyuarakan tulisan dengan intonasi yang wajar, sebagai dasar untuk dapat membaca lanjut. Pernyataan tersebut juga sejalan dengan pendapat Syafi'ie (1999: 16) yang menyatakan bahwa membaca lanjut menekankan pada pemahaman isi bacaan, sehingga perlu perbaikan dan penyempurnaan penguasaan teknik pada saat membaca permulaan.

\section{SIMPULAN DAN SARAN}

Berdasarkan hasil pengamatan permainan batu loncatan di kelas, aktivitas siswa sangat bagus.Siswa merespons permainan yang belum pernah dilakukan sebelumnya. Meskipun permainan sederhana namun menarik siswa, karena siswa tidak hanya bermain saja tetapi belajar menghafal kata dan kalimat. Sehingga siswa tidak hanya aktif bermain tapi juga bertambah kemampuan mengolah kata dalam ingatannya. Hal ini dipertegas oleh Tarigan (2002: 33) yang menyatakan bahwa kegiatan bermain sangat penting dalam pengembangan kemampuan berbahasa anak. Seringkali mereka berperilaku sebagai anak atau orang yang lebih tua, bahkan ada yang berperan sebagai guru atau murid dalam permainan sekolahsekolahan. Dalam permainan itu mereka seolah-olah berdrama dan tanpa disadari mereka berlatih berbicara dan menyimak.

Berdasarkan kesimpulan penelitian, saran yang dapat disampaikan bagi kepala sekolah, pembelajaran membaca melalui kegiatan permainan bahasa perlu dikembangkan lagi sebagai salah satu kegiatan pembelajaran yang variatif bagi guru. Bagi guru, pengetahuan bahasa perlu ditingkatkan agar pembelajaran yang disampaikan mudah dipahami oleh siswa. Pengetahuan tersebut tidak hanya berupa kegiatan belajar saja namun juga divariasi dengan permainan yang dapat digunakan siswa tidak hanya pada waktu pelajaran saja namun di luar kelas. Bagi peneliti yang lain, penelitian tentang membaca permulaan dengan permainan bahasa dapat dilanjutkan untuk penelitian jenis membaca yang lain yang tentunya dengan kegiatan dan metode yang berbeda dengan penelitian ini. 


\section{DAFTAR RUJUKAN}

Akhadiah, S. 1993. Pedoman Pelaksanaan Pembelajaran Membaca di SD: Materi Ajar PGSD FIP UNJ. Jakarta: Universitas Negeri Jakarta.

BSNP SD / MI. 2006. Standar Kompetensi dan Kompetensi Dasar Bahasa Indonesia SD /MI. Jakarta: BSNP.

Azies, F., dan Alwasilah, A. C. 1996.Pengajaran Bahasa Komunikatif: Teori dan Praktek. Bandung: Remaja Rosdakarya.

Badudu, J. S. 1993. Pengajaran Bahasa Indonesia di Sekolah Menengah: Tinjauan dari Masa ke Masa. Yogyakarta: Kanasius.

Baradja, M. F. 1990. Kapita Selekta Pengajaran Bahasa. Malang: IKIP Malang.

Depdikbud. 1994. Petunjuk Pelaksanaan Kegiatan Belajar Mengajar di Sekolah Dasar. Jakarta: Depdikbub.

Gibbons, P. 1993. Learning to Learn in a Second Language. Australia: Heinemann Portmourth NH.

Iskandarwassid, dan Sunendar, D. 2011.Strategi Pembelajaran Bahasa. Bandung: Remaja Rosdakarya.

Muchlisoh. 1992. Materi Pokok Bahasa Indonesia 3. Jakarta: Depdikbud.

Pollit, T. 1994. How Play and Work are Organized in Kindergarten Classroom. Journal of Research in Childhood Education, 9(1): 32-45.

Pusat Kurikulum, Balitbang Diknas. 2002. Kurikulum Berbasis Kompetensi. Jakarta: Depdiknas.

Pusat Pembinaan dan Pengembangan Bahasa. 1996. Kamus Besar Bahasa Indonesia. Jakarta: Balai Pustaka.

Root, B. 1995. Membantu Putra Anda Belajar Membaca. Jakarta: Periplus.

Rofi'uddin, A. 2003. Faktor Kreativitas dalam Kemampuan Membaca dan Menulis Siswa Kelas V Sekolah Dasar Islam Sabilillah Malang. Lemlit Universitas Negeri Malang.

Rahim, F. 2007. Pengajaran Membaca di Sekolah Dasar. Jakarta: Bumi Aksara.

Semiawan, C. R. 2002. Belajar dan Pembelajaran dalam Taraf Usia Dini. Jakarta: PT Ikrar Mandiri Abadi.

Smith, F. 1985. Reading. Cambridge: Camoridge University Press. 
Slamet, S. Y. 2008. Dasar-Dasar Ketrampilan Berbahasa Indonesia. Surakarta: LPP UNS dan UPT Penerbitan dan Percetakan UNS.

Soemarwoto, V. D. 2011. Implementasi Profesionalisme Guru dalam Memotivasi Belajar Siswa di Sekolah Dasar. Premiere Educandum, 1(2): 1-25.

Syafi'ie, I. 1999. Pengajaran Membaca di Kelas - Kelas Awal Sekolah Dasar. Pidato Pengukuhan Guru Besar dalam Bidang Ilmu Pengajaran Bahasa Indonesia pada FPBS Universitas Negeri Malang. Malang: Universitas Negeri Malang.

Tarigan, H. 2008. Membaca Sebagai Suatu Ketrampilan Berbicara. Bandung: Angkasa.

Wood, J. T. 1996. Human Communication: A Simbolic Interactionist Perspective. New York: Holt, Rinchart and Winston. 